\title{
Forms and Dynamics of Soil Potassium in Acid Soil in the Wolaita Zone of Southern Ethiopia
}

\author{
Mesfin Kassa $\mathbb{D}^{1},{ }^{1}$ Fassil Kebede, ${ }^{2}$ and Wassie Haile ${ }^{3}$ \\ ${ }^{1}$ Department of Plant Science, College of Agricultural, Wolaita Sodo University, P.O Box 138, Sodo, Ethiopia \\ ${ }^{2}$ Mohammed VI Polytechnic University Lot 660, Haymoulary Rachid 43150, Ben Guerir, Morocco \\ ${ }^{3}$ School of Plant and Horticultural Science, Hawassa University, P. O. Box 05, Hawassa, Ethiopia \\ Correspondence should be addressed to Mesfin Kassa; mesfine2004@gmail.com
}

Received 25 March 2021; Revised 25 August 2021; Accepted 12 October 2021; Published 26 October 2021

Academic Editor: Francesco De Mastro

Copyright (@) 2021 Mesfin Kassa et al. This is an open access article distributed under the Creative Commons Attribution License, which permits unrestricted use, distribution, and reproduction in any medium, provided the original work is properly cited.

Quantity-intensity (Q/I) characteristics are among conventional approaches for studying potassium dynamics and its availability. This was assessed to determine availability in four districts: namely, Sodo Zuria, Damot Gale, Damot Sore, and Boloso Sore, at three different land use systems (enset-coffee, crop land, and grazing land). Fractionation and dynamics of $\mathrm{K}$ sources were studied in soil samples, which were collected from $0-20 \mathrm{~cm}$ depth of each land system. The study revealed that water extractable $\mathrm{K}\left(\mathrm{H}_{2} \mathrm{O}-\right.$ $\mathrm{K})$ concentrations ranged from 0.13 to $0.34 \mathrm{cmolc} \mathrm{kg}^{-1}$ soils at enset-coffee and grazing land use systems, respectively, and had a mean value of $0.28 \mathrm{cmolc} \mathrm{kg}^{-1}$ soils ammonium acetate extractable $\left(\mathrm{NH}_{4} \mathrm{OAC}-\mathrm{K}\right)$ and nitric acid extract $\left(\mathrm{HNO}_{3}-\mathrm{K}\right)$ had a mean value of $0.25 \mathrm{cmolc} \mathrm{kg}^{-1}$ soils. In this study, the means of nonexchangeable- and exchangeable-K concentrations were of 0.11 and $0.14 \mathrm{cmolc} \mathrm{kg}^{-1}$ soils for land use types. Significant correlations were found between soil properties and Q/I parameters and among equilibrium solution parameters and Q/I parameters. There was no significant variation among the mean quantity values of the soils. The soils had higher change in exchangeable-K and potential buffering capacity than the enset-coffee land use soils, and the cop land had the highest values for these parameters. However, the enset-coffee land use soils had higher K-intensity. Therefore, application of site specific soil fertility management practices and research can improve soil K status and Q/I parameters to sustain productivity soils.

\section{Introduction}

Potassium is an essential and major nutrient for agricultural crop production [1]. Potassium exists in four forms in the soil, such as solution, exchangeable, nonexchangeable, or fixed and mineral or structural $\mathrm{K}$ forms [2]. The distribution of soil $\mathrm{K}$ among water soluble, exchangeable, and nonexchangeable forms is related to many soil properties including surface area, mineralogy, surface charge density, and degree of interlayering of clay minerals $[3,4]$. There are dynamic, equilibrium reactions between different forms of $\mathrm{K}$ in different soils depending on the parent material, degree of weathering, fertilizer, losses due to crop removal, erosion, and leaching [5]. Quantity-intensity relationship has been used to measure the availability of potassium in soils [6]. This relationship implies that the ability of a soil system to maintain a certain concentration of a cation in solution is determined by the total amount of the cation present in readily available forms (exchangeable and soluble) and the intensity by which it is released into the soil solution [5]. Various interpretations of the thermodynamic parameters have been made, which can be derived from a Q/I plot [7]. In particular soil contains considerable amount of $\mathrm{K}$, the availability to plants is negligible because the availability of $\mathrm{K}$ to plants depends not only on its availability but also on its dynamics, viz., intensity, capacity, and renewal rate in soils, and the equilibrium constant is vital for predicting the status and supply of $\mathrm{K}$ for plant [8]. Inadequate and unbalanced fertilizer application may be one reason for declining $\mathrm{K}$ nutrition in crop fields that results in lower crop yield. The low levels of exchangeable- $\mathrm{K}$ in many of the farming contradict with the generally held view that Ethiopia soils are 
rich in potassium. Several studies revealed that any activity associated with change in land use and agricultural management practices can affect soil properties and $\mathrm{K}$ dynamics [9-12], but the exchangeable and extractable $\mathrm{K}$ status of Wolaita soil $\mathrm{K}$ forms are unsatisfactory measures of nutrient availability since their concentration in the soil at any time is small in relation to long-term losses by crop removal and leaching and they give little indication of reserves of nonexchangeable but potentially available $\mathrm{K}$. As limited research results are available on the balance of $\mathrm{K}$ for crop land systems in Kassa et al. [13], the ability to predict yield responses to $\mathrm{K}$ fertilizers from K soil tests is limited and requires study; the objectives of this study were to (1) determine physical and chemical properties of the soils and (2) assess different types of $\mathrm{K}$ forms and dynamic in the different land uses.

\section{Materials and Methods}

2.1. Description of the Study Sites. The study sites were located in Sodo Zuria, Damot Gale, Damot Sore, and Boloso Sore districts of the Wolaita Zone of Southern Ethiopia (Figures 1 and 2) during 2015. Wolaita Zone is situated in longitude $37^{\circ} 35^{\prime} 30^{\prime \prime}$ to $38^{\circ} 58^{\prime} 36^{\prime \prime} \mathrm{N}$ and latitude $6^{\circ} 57^{\prime} 20^{\prime \prime}$ to $7^{\circ} 04^{\prime} 31^{\prime \prime} \mathrm{E}$, with altitude ranges from 1895 to 2260 meters above sea level. The average annual rainfall ranges from 1000 to $1394.82 \mathrm{~mm}$ with mean annual temperature of $19.93^{\circ} \mathrm{C}$ ([14], Figure 2). The main crops grown in the area include maize, beans, bananas, sugarcane, coffee, cassava, and cabbage. The dominant soil around Wolaita area is Eutric Nitisols, associated with Humic Nitisols, and mineralogy of the soil is kaolinite $[15,16]$.

2.2. Site Selection, Soil Sampling Procedures, and Layout. The sites and land use systems were selected by conducting visual physical observation of the area to have a general view of the variations in the study during 2014. During physical observation, the geographical position of the area was observed, which is similar in agroecology and altitude and slope were selected purposively. After the selection of the two peasant associations, the land use systems were systematically selected on the basis of geographical position, similarity in soil color by visual observation, slope, and altitude to reduce their natural difference as well as soil type diversity impacts on the soil acidity. Different land use systems (enset-coffee, crop, and grazing lands) that are adjacent to each other were selected for soil sampling sites. Sampling from each land use system and location was replicated four times. Therefore, a total of 48 disturbed soil samples were collected; then the collected soil samples were composited treatment-wise to 12 representative composite soil samples. Finally, the composite soil samples were subjected to laboratory analysis for selected soil physical and chemical properties.

2.3. Soil Laboratory Analysis. All laboratory analyses were done by following the procedures in laboratory manual prepared by Sertsu and Taye [17]. Particle size distribution was determined by hydrometer method [18]. Soil pH and electrical conductivity (EC) were measured using $1: 2.5$ soil: water ratio [19], whereas organic carbon (OC) was measured by wet digestion method [20]. Total $\mathrm{N}$ was determined by Kjeldahl wet digestion and distillation method [21], available P by using Bray II method [22], and available potassium by Morgan [23]. The cation exchange capacity (CEC) and exchangeable bases were extracted by $1 \mathrm{M}$ ammonium acetate ( $\mathrm{pH}$ 7) method [24]. In the extract, exchangeable $\mathrm{Ca}$ and $\mathrm{Mg}$ were determined by atomic absorption spectrophotometer (AAS) and exchangeable- $\mathrm{K}$ and $\mathrm{Na}$ by flame photometer. Calcium carbonate was determined by the acid neutralization method and exchangeable acidity was determined by titration with $\mathrm{NaOH}$ after extraction with $1 \mathrm{~N}$ $\mathrm{KCl}$ in the ratio $1: 20$ and exchangeable acidity was determined. Available micronutrients ( $\mathrm{Fe}, \mathrm{Mn}, \mathrm{Zn}$, and $\mathrm{Cu}$ ) of the soil were extracted by diethylenetriaminepentaacetic acid method [25] and determined using AAS.

The water soluble ammonium acetate extractable potassium and nitric acid extract potassium were determined by the methods described by Pratt [26]. Exchangeable-K (Exch-K) was calculated by subtracting $\mathrm{H}_{2} \mathrm{O}-\mathrm{K}$ from $\mathrm{NH}_{4} \mathrm{OAC}-\mathrm{K}$ and nonexchangeable- $\mathrm{K}$ was calculated by subtracting (Exch-K) from $1 \mathrm{NHNO}_{3}$ extractable $\mathrm{K}$ obtained according to the mathematical procedures used by [27]. The concentration of potassium in all extracts was measured by flame photometer. Quantity-Intensity (Q/I) isotherm was constructed according to the modified method of Wang et al. [7]. Soil samples weighing five grams were placed in preweighed centrifuge tubes of $30 \mathrm{~mL}$ volume and then in each tube $30 \mathrm{~mL}$ of $0.01 \mathrm{M} \mathrm{CaCl}_{2}$ solution was added with $\mathrm{KCl}$ at concentrations of $0,0.2,0.4$, $0.8,2.0,4.0$, and $8.0 \mathrm{mg} \cdot \mathrm{L}^{-1} \cdot \mathrm{K}$. In order to include more points at the K-release part of the isotherms as suggested by Wang et al. [7], soil samples of five grams were added and mixed with $30 \mathrm{~mL}$ of $\mathrm{CaCl}_{2}$ solution $(0.01 \mathrm{M})$, without $\mathrm{KCl}$ addition. The bottles were shaken for $1 \mathrm{hr}$ and allowed to stand for 24 hours to attain equilibrium. After the $24 \mathrm{hrs}$ equilibrium period, supernatant solution was collected after centrifugation at $2000 \mathrm{rpm}$ for $10 \mathrm{~min}$ and $\mathrm{K}, \mathrm{Ca}$, and $\mathrm{Mg}$ were determined by flame photometry and flame atomic absorption spectrometry (AAS), respectively. An activity ratio was calculated with the Debye-Huckel equation, $\log \gamma_{i}=-0.509 \mathrm{Z}^{2} \mathrm{I}^{1 / 2}$, where $Z$ is valence of ion, $\gamma_{i}=$ activity coefficient, and $I=$ Ionic strength. All equations that calculate activity coefficients were based on a solution parameter termed ionic strength. Ionic strength (I) $(\mu)$ mol $\mathrm{L}^{-1}$ in soil extracts was calculated by the formula proposed by Griffin and Jurinak [28]: $I=0.0129 \mathrm{ECe}\left(\mathrm{dSm}^{-1}\right)$. Activities of potassium, calcium, and magnesium in the extracts were calculated as product of concentration of ions multiplied by their activity coefficient $(\gamma)$ values. Activity $(a)=\gamma \mathrm{M}$, where $M=$ concentration of the cations in solution $\left(\right.$ mols $\mathrm{L}^{-1}$ ). The activities (a) ratio of $\mathrm{K}$ in the solutions was determined by using the equation $A R^{K}=a K / \sqrt{ } a(C a+M g)$, the free energy of replacement $(-\Delta \mathrm{F})$ of $\mathrm{K}$ was calculated by the formula proposed by Woodruff [29]: $-\Delta \mathrm{F}=2.303 \mathrm{RTLog} \mathrm{AR}^{\mathrm{K}}$, where $R$ is gas constant $\left(1.987 \mathrm{Cal} \mathrm{K} \mathrm{mol}^{-1}\right)$ and $T$ is the absolute temperature $25^{\circ} \mathrm{C}$; lower than $(\Delta \mathrm{F})-3500 \mathrm{cal} \mathrm{mol}^{-1},-3500$ to 


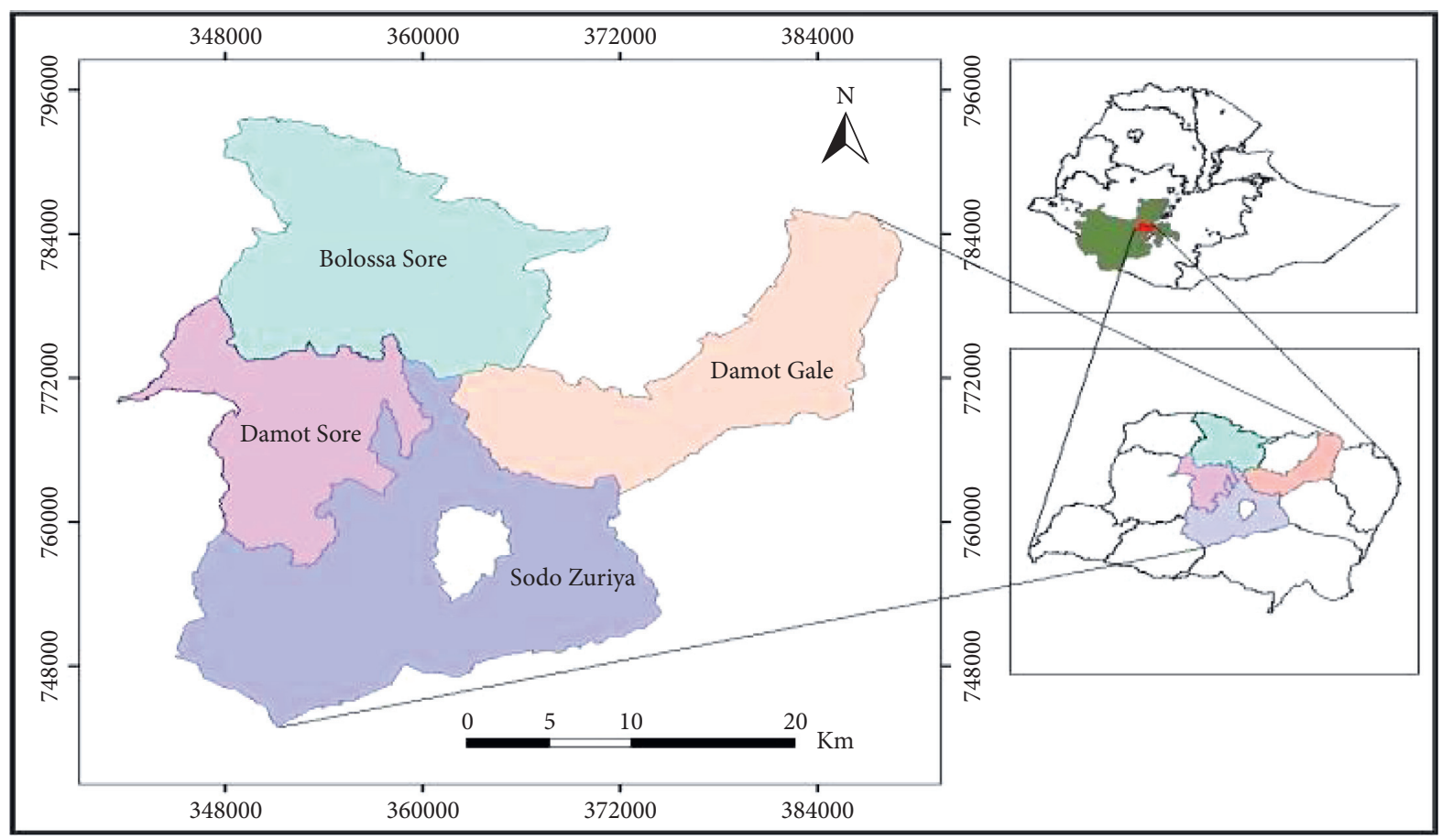

FIgURE 1: Locations map of the Wolaita Zone in Ethiopia.

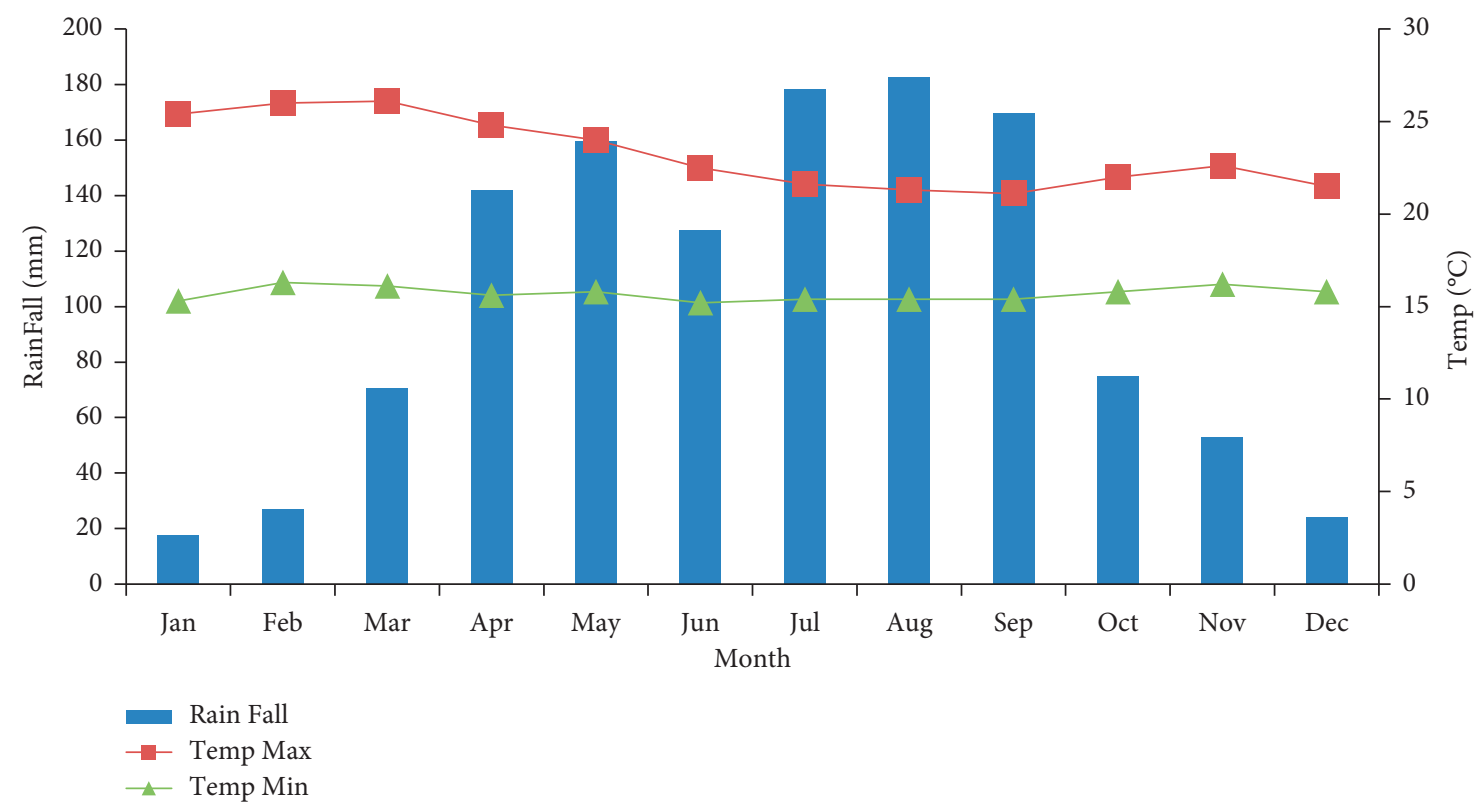

FIGURE 2: Nine-year (2008-2016) mean monthly rainfall and mean maximum and minimum temperatures of the study areas [14].

$-2000 \mathrm{cal} \mathrm{mol}^{-1}$, and greater than $-2000 \mathrm{cal} \mathrm{mol}^{-1}$ soil have poor, medium, and high supplying power of potassium, respectively. The gain/loss of $K( \pm \Delta K)$ in relation to the adsorbed phase was calculated by measuring the corresponding increase or decrease in the concentration of $\mathrm{K}$ in the equilibrium solution, compared to the original solution. Potassium buffering capacity $\left(\mathrm{PBC}^{\mathrm{K}}\right)= \pm \Delta \mathrm{K}^{0} / \mathrm{ARe}^{\mathrm{K}}$, where $-\Delta \mathrm{K}^{0}=$ Labile $\mathrm{K} \quad$ (quantity of $\mathrm{K}$ released) and
$\mathrm{ARe}^{\mathrm{K}}=$ Equilibrium activity ratio. The quantity factor represents the change in exchangeable potassium $( \pm \Delta K)=$ $[\mathrm{K}]$ original- $[\mathrm{K}]$ equilibrium or the change in the amount of exchangeable potassium $( \pm \Delta K)$ which represents the quantity factor was calculated from the differences of concentrations of potassium in prepared solutions and equilibrated solution and the intensity factor is the activity ratio of potassium. 
2.4. Statistical Analysis. The data were subjected to analysis of variance (ANOVA) by using SAS software. Treatment means were compared using LSD at Probability 5\% level.

\section{Results and Discussion}

3.1. Selected Physical and Chemical Properties of the Soils. The textural class determinations revealed that the soils were dominated by sandy clay loam, with silt loam (crop land) and sandy loam (grazing) fractions (Table 1). Accordingly, the soil texture varied from silt loam to loam in the crop land. This might be attributed to the removal of fine soil particles from crop land and their deposition at lower surface. The soil $\mathrm{pH} \mathrm{KCl}$ and $\mathrm{H}_{2} \mathrm{O}$ varied from 4.08 to 5.60 and 5.05 to 6.61 in enset-coffee and crop land, respectively, which are slightly acidic and very acidic [30]. In addition, higher $\mathrm{pH}$ (6.6) was recorded under ensetcoffee as compared crop land (5.05), which could be attributed to the relatively high erosion and leaching of exchangeable bases. Ishibashi et al. [31] reported that the increasing rates of nitrogenous fertilizers also increase soil acidity. The OC of the soils ranged from 0.49 to $2.02 \%$ under different land use; higher OC (2.02\%) was recorded under enset-coffee as compared crop land (0.49\%), which could be attributed to increase in the biological soil microorganisms, soil moisture and aeration, dominance of roots, humus, and addition of biomass under enset-coffee land system. Similarly, Yihenew [32] stated that Ethiopia cultivated soils are poor in organic matter due to low amount of organic materials applied to the soil and nearly complete removal of the biomass from the field. According to Landon [33] classification TN was low in all experimental sites. Total $\mathrm{N}$ was significantly $(P \leq 0.05)$ affected by land use and location interactions (Table 1). Comparatively, the highest $(0.18 \%)$ was recorded under enset-coffee and the lowest $(0.11 \%)$ under crop land. Available P content of the soils ranged from 6.4 to $18.96 \mathrm{mg} \mathrm{kg}^{-1}$ and was low in accordance with Landon rating [33] throughout the locations (Table 1) indicating its inadequacy for crop production could be attributed to fixation on both clay surfaces. The CEC of the soils ranged from 15 to 24 $\mathrm{cmolc} \mathrm{kg}^{-1}$ soils and was medium value as per the rating of Hazelton and Murphy [30]. The soil was low in exchangeable base which is due to the higher rainfall and seasonal variation normally observed in the area leading to intense leaching of bases and accumulation of exchangeable acidity in these soils. Highly significant $(P \leq 0.01)$ differences were observed in available micronutrients of $\mathrm{Fe}, \mathrm{Mn}$, and $\mathrm{Zn}$ contents by the interaction effect of land uses and locations where the highest (178.2, 144 , and $10.20 \mathrm{mg} \mathrm{kg}^{-1}$ ) were observed under the crop and grazing land (Table 2), which might be due to OM concentrations that acted as a chelating effect and source of such micronutrients. Significant difference was observed in $\mathrm{Cu}$ content where the highest $\left(4.98 \mathrm{mg} \mathrm{kg}^{-1}\right)$ was recorded under grazing land that might be also due to its soil OM contents. This result is in agreement with that of Alemayehu and Sheleme [34] who reported that available $\mathrm{Cu}$ was deficient in enset and maize land use systems.
3.2. Effects of Land Use Systems on Soil Potassium Forms. The $\mathrm{H}_{2} \mathrm{O}-\mathrm{K}$ in the soils ranged from 0.04 to $0.42 \mathrm{cmolc} \mathrm{kg}^{-1}$ soil under different land uses and was high according to IPI [35]. Significantly higher $\mathrm{H}_{2} \mathrm{O}-\mathrm{K}$ was observed under ensetcoffee complex compared to grazing land $\left(0.04 \mathrm{cmolc} \mathrm{kg}^{-1}\right.$ soil), showing that solution $\mathrm{K}$ constitutes an insignificant fraction of $\mathrm{K}$ available for plant uptake or leaching in the various land use systems. Other workers have reported 0.002 cmolc kg-1 soil to $0.02 \mathrm{cmolc} \mathrm{kg}^{-1}$ soil for major Lebanese agricultural soils [36] and $0.004 \mathrm{cmolc} \mathrm{kg}^{-1}$ soil to 0.046 cmolc $\mathrm{kg}^{-1}$ soil for paddy and nonpaddy rice soils in Iran [37]. The $\mathrm{NH}_{4} \mathrm{OAC}-\mathrm{K}$ in the soils ranged from 0.17 to 0.61 cmolc $\mathrm{kg}^{-1}$ soil and was low in accordance with the rating of Darwish et al. [38]. Highly significant $(P \leq 0.001)$ difference was observed in $\mathrm{NH}_{4} \mathrm{OAC}-\mathrm{K}$ by the interaction effects of land uses and locations where the highest was observed in the enset-coffee land as compared to crop and grazing lands, which might be long-term overgrazing and continuous cropping without replenishing with potassium fertilizers (Table 3). This result is in agreement with that of Darwish et al. [38] who reported that $\mathrm{NH}_{4} \mathrm{OAC}-\mathrm{K}$ values for some Lebanese soils ranged from 0.4 to $2.0 \mathrm{cmolc} \mathrm{kg}^{-1}$ soil, 132.74 to $546.59 \mathrm{mg} \mathrm{kg}^{-1}$ for soils under banana land use in Ethiopia [39], and 49.70 to 803.14 for rice in tropical savanna climate of Thailand soils [40]. The $\mathrm{HNO}_{3}-\mathrm{K}$ was low in accordance with the rating of [33]. Significantly highest value was observed under enset-coffee as compared to crop and grazing lands (Table 3), which is attributed to the different types of parent rock and mineralogy of the studied soils and the soil supplying power for potassium for long-term cropping and the soils have poor supplying power of potassium for future cropping and plant growth. This result is in agreement with that of Al-Zubaidi [41] who reported on Iraqi soils (580 to $\left.2200 \mathrm{mg} \mathrm{kg}^{-1}\right)$. The data presented in Table 3 indicated that value of exchangeable-K ranged from 0.05 to 0.0 .19 cmolc $\mathrm{kg}^{-1}$ soil. It was highly significantly $(P \leq 0.001)$ affected by land uses and locations interactions whereby the

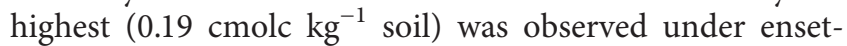
coffee as compared to crop land, which shows the exchangeable-K status of these soils was low for sustainable crop production in crop land uses, thus the need for supplemental application of $\mathrm{K}$ fertilizer, and crop land soils have exchangeable-K occupancy of the exchange sites. Al-Zubaidi et al. [36] suggested that the critical exchangeable-K requirement for most crops is $0.41 \mathrm{cmolc} \mathrm{kg}^{-1}$ soil, while an exchangeable-K value of $0.30 \mathrm{cmolc} \mathrm{kg}^{-1}$ soil was adopted by Ajiboye et al. [5]. In addition, Darryl et al. [22] suggested that the critical exchangeable-K requirement of the soils for good crop yield was $0.27 \mathrm{cmolc} \mathrm{kg}^{-1}$ soil; the value was also higher than $0.05 \mathrm{cmolc} \mathrm{kg}^{-1}$ soil exchangeable-K content of these soils, suggesting that the exchangeable-K levels of these soils were deficient for crop production. The nonexchangeable- $\mathrm{K}$ in the soils ranged from 0.01 to $0.29 \mathrm{cmolc} \mathrm{kg}^{-1}$ soil and was low according to Srinivasarao et al. [42] who proposed 0.8 cmolc $\mathrm{kg}^{-1}$ soil content in reserve $\mathrm{K}$ which is highly significantly $(P \leq 0.001)$ affected by land uses and locations interactions, whereas the highest $\left(0.29\right.$ cmolc $\mathrm{kg}^{-1}$ soil $)$ was observed under enset-coffee complex as compared to crop land, which might be also due to the weathering action of soil 
TABLE 1: Selected physical and chemical properties of the soils as influenced by land uses and locations.

\begin{tabular}{|c|c|c|c|c|c|c|c|c|c|c|c|c|}
\hline Location & Land use & $\begin{array}{c}\text { Sand } \\
(\%)\end{array}$ & $\begin{array}{l}\text { Silt } \\
(\%)\end{array}$ & $\begin{array}{l}\text { Clay } \\
(\%)\end{array}$ & $\begin{array}{c}\text { Textural } \\
\text { class }\end{array}$ & $\begin{array}{c}\mathrm{pH} \\
\left(\mathrm{H}_{2} \mathrm{O}\right)\end{array}$ & $\begin{array}{c}\mathrm{pH} \\
(\mathrm{KCl})\end{array}$ & $\begin{array}{l}\text { OC } \\
(\%) \\
\end{array}$ & $\begin{array}{c}\mathrm{EC} \\
\left(\mathrm{dSm}^{-1}\right)\end{array}$ & $\begin{array}{c}\text { Ava. P } \\
\left(\mathrm{mg} \mathrm{kg}^{-1}\right)\end{array}$ & $\begin{array}{c}\text { Ava. K } \\
\left(\mathrm{mg} \mathrm{kg}^{-1}\right)\end{array}$ & $\begin{array}{c}\mathrm{TN} \\
\% \\
\end{array}$ \\
\hline \multirow{3}{*}{$\begin{array}{l}\text { Sodo } \\
\text { Zuria }\end{array}$} & $\begin{array}{l}\text { Enset- } \\
\text { coffee }\end{array}$ & 54.00 & 22.00 & 24.00 & SCL & 6.36 & 5.38 & 1.95 & .0 .15 & 17.50 & 306.8 & 0.18 \\
\hline & $\begin{array}{l}\text { Crop } \\
\text { land }\end{array}$ & 38.01 & 44.01 & 18.00 & $\mathrm{~L}$ & 5.56 & 4.40 & 1.56 & 0.53 & 7.50 & 149.3 & 0.15 \\
\hline & $\begin{array}{l}\text { Grass } \\
\text { land }\end{array}$ & 68.00 & 20.00 & 12.00 & SL & 5.97 & 4.86 & 1.61 & 0.42 & 10.30 & 180.7 & 0.15 \\
\hline \multirow{3}{*}{$\begin{array}{l}\text { Damot } \\
\text { Gale }\end{array}$} & $\begin{array}{l}\text { Enset- } \\
\text { coffee }\end{array}$ & 36.00 & 37.00 & 27.00 & $\mathrm{CL}$ & 6.61 & 5.60 & 2.12 & 0.11 & 19.10 & 314.8 & 0.18 \\
\hline & $\begin{array}{l}\text { Crop } \\
\text { land }\end{array}$ & 26.00 & 50.00 & 24.00 & SiL & 5.05 & 4.84 & 1.56 & 0.32 & 6.90 & 123.9 & 0.11 \\
\hline & $\begin{array}{l}\text { Grass } \\
\text { land }\end{array}$ & 60.00 & 16.00 & 24.00 & SCL & 5.52 & 4.08 & 2.02 & 0.43 & 6.40 & 197.8 & 0.11 \\
\hline \multirow{3}{*}{$\begin{array}{l}\text { Damot } \\
\text { Sore }\end{array}$} & $\begin{array}{l}\text { Enset- } \\
\text { coffee }\end{array}$ & 36.00 & 42.00 & 26.00 & $\mathrm{~L}$ & 6.12 & 5.07 & 2.34 & 0.21 & 17.09 & 264.5 & 0.16 \\
\hline & $\begin{array}{l}\text { Crop } \\
\text { land }\end{array}$ & 19.0 & 55.0 & 22.0 & $\mathrm{SiL}$ & 5.54 & 4.23 & 0.49 & 0.33 & 7.20 & 105.0 & 0.12 \\
\hline & $\begin{array}{l}\text { Grass } \\
\text { land }\end{array}$ & 27.00 & 51.00 & 22.00 & SiL & 6.01 & 4.23 & 0.98 & 0.23 & 7.19 & 141.8 & 0.12 \\
\hline \multirow{6}{*}{$\begin{array}{l}\text { Boloso } \\
\text { Sore }\end{array}$} & $\begin{array}{l}\text { Enset- } \\
\text { coffee }\end{array}$ & 40.00 & 36.00 & 24.00 & $\mathrm{~L}$ & 5.92 & 5.09 & 2.44 & 0.55 & 18.96 & 234.6 & 0.14 \\
\hline & $\begin{array}{l}\text { Crop } \\
\text { land }\end{array}$ & 28.00 & 50.00 & 22.00 & $\mathrm{SiL}$ & 5.05 & 5.55 & 0.88 & 0.43 & 7.39 & 158.3 & 0.14 \\
\hline & $\begin{array}{l}\text { Grass } \\
\text { land }\end{array}$ & 30.00 & 40.00 & 30.00 & $\mathrm{CL}$ & 5.08 & 4.76 & 1.12 & 0.52 & 6.97 & 223.6 & 0.13 \\
\hline & Means & 37.49 & 36.86 & 20.91 & - & 5.88 & 4.85 & 1.81 & 0.35 & 10.67 & 195.12 & 0.14 \\
\hline & CV (\%) & 2.95 & 6.13 & 9.56 & - & 11.87 & 4.85 & 7.75 & 4.80 & 5.53 & 2.52 & 3.61 \\
\hline & $\begin{array}{l}\text { LSD } \\
(5 \%)\end{array}$ & 0.93 & 1.90 & 1.68 & - & 0.58 & 0.19 & 0.11 & 0.17 & 0.49 & 2.11 & 0.04 \\
\hline
\end{tabular}

$\mathrm{SCL}=$ sand clay loam, $L=$ loam, $\mathrm{SL}=$ sandy loam, $\mathrm{CL}=$ clay loam, $\mathrm{SiL}=$ silt loam, $\mathrm{SCL}=$ sandy clay loam, $L=$ loam, $\mathrm{SiL}=$ silt loam, $\mathrm{CL}=$ clay loam, EncL $=$ enset-coffee system, $\mathrm{CL}=$ crop land, $\mathrm{GL}=$ grazing land .

TABLE 2: Selected physical and chemical properties of the soils as influenced by land uses and locations.

\begin{tabular}{|c|c|c|c|c|c|c|c|c|c|c|c|c|}
\hline \multirow[t]{2}{*}{ Location } & \multirow{2}{*}{$\begin{array}{l}\text { Land } \\
\text { use }\end{array}$} & \multicolumn{4}{|c|}{$\begin{array}{l}\text { Exchangeable base } \\
\quad\left(\mathrm{cmolc} \mathrm{kg}^{-1}\right)\end{array}$} & \multirow{2}{*}{ 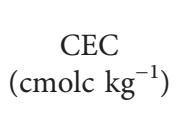 } & \multirow{2}{*}{$\begin{array}{c}\mathrm{CaCO}_{3} \\
(\%)\end{array}$} & \multirow{2}{*}{$\begin{array}{l}\text { DTPA Fe } \\
\left(\mathrm{mg} \mathrm{kg}^{-1}\right)\end{array}$} & \multirow{2}{*}{$\begin{array}{l}\text { DTPA Mn } \\
\left(\mathrm{mg} \mathrm{kg}^{-1}\right)\end{array}$} & \multirow{2}{*}{$\begin{array}{l}\text { DTPA Zn } \\
\left(\mathrm{mg} \mathrm{kg}^{-1}\right)\end{array}$} & \multirow{2}{*}{$\begin{array}{c}\text { DTPA } \\
\mathrm{Cu}\left(\mathrm{mg} \mathrm{kg}^{-1}\right)\end{array}$} & \multirow{2}{*}{$\begin{array}{c}\text { Exchangeable } \\
\text { acidity } \\
\left(\mathrm{cmolc} \mathrm{kg}^{-1}\right)\end{array}$} \\
\hline & & $\mathrm{K}$ & $\mathrm{Ca}$ & $\mathrm{Mg}$ & $\mathrm{Na}$ & & & & & & & \\
\hline \multirow{3}{*}{$\begin{array}{l}\text { Sodo } \\
\text { Zuria }\end{array}$} & $\begin{array}{l}\text { Enset- } \\
\text { coffee }\end{array}$ & 0.17 & 12.40 & 7.44 & 0.27 & 22.00 & 21.50 & 74.00 & 98.00 & 8.20 & 3.40 & 0.42 \\
\hline & $\begin{array}{l}\text { Crop } \\
\text { land }\end{array}$ & 0.16 & 10.60 & 5.74 & 0.13 & 15.00 & 19.70 & 102 & 115.0 & 10.20 & 1.80 & 0.64 \\
\hline & $\begin{array}{l}\text { Grass } \\
\text { land }\end{array}$ & 0.15 & 11.40 & 7.58 & 0.14 & 17.00 & 21.20 & 96.00 & 105.0 & 8.80 & 3.20 & 0.56 \\
\hline \multirow{3}{*}{$\begin{array}{l}\text { Damot } \\
\text { Gale }\end{array}$} & $\begin{array}{l}\text { Enset- } \\
\text { coffee }\end{array}$ & 0.18 & 11.60 & 6.74 & 0.29 & 20.00 & 22.20 & 124.00 & 128.00 & 10.60 & 3.20 & 0.37 \\
\hline & $\begin{array}{l}\text { Crop } \\
\text { land }\end{array}$ & 0.07 & 10.60 & 5.15 & 0.37 & 15.00 & 18.50 & 146.00 & 145.00 & 10.80 & 1.50 & 0.51 \\
\hline & $\begin{array}{l}\text { Grass } \\
\text { land }\end{array}$ & 0.05 & 11.60 & 6.26 & 0.41 & 17.00 & 19.70 & 134.0 & 138.0 & 10.20 & 4.80 & 0.47 \\
\hline \multirow{3}{*}{$\begin{array}{l}\text { Damot } \\
\text { Sore }\end{array}$} & $\begin{array}{l}\text { Enset- } \\
\text { coffee }\end{array}$ & 0.19 & 14.40 & 7.44 & 0.36 & 23.00 & 23.00 & 121.0 & 108.0 & 10.20 & 4.80 & 0.32 \\
\hline & $\begin{array}{l}\text { Crop } \\
\text { land }\end{array}$ & 0.05 & 12.6 & 6.15 & 0.35 & 20.0 & 19.6 & 164 & 157 & 10.6 & 1.60 & 0.40 \\
\hline & $\begin{array}{l}\text { Grass } \\
\text { land }\end{array}$ & 0.13 & 14.50 & 7.26 & 0.35 & 24.00 & 20.20 & 157.0 & 144.0 & 10.40 & 4.74 & 0.40 \\
\hline
\end{tabular}


TABLE 2: Continued.

\begin{tabular}{|c|c|c|c|c|c|c|c|c|c|c|c|c|}
\hline \multirow[t]{2}{*}{ Location } & \multirow{2}{*}{$\begin{array}{l}\text { Land } \\
\text { use }\end{array}$} & \multicolumn{4}{|c|}{$\begin{array}{l}\text { Exchangeable base } \\
\left(\mathrm{cmolc} \mathrm{kg}^{-1}\right)\end{array}$} & \multirow{2}{*}{$\begin{array}{c}\text { CEC } \\
\left(\mathrm{cmolc} \mathrm{kg}^{-1}\right)\end{array}$} & \multirow{2}{*}{$\begin{array}{c}\mathrm{CaCO}_{3} \\
(\%)\end{array}$} & \multirow{2}{*}{$\begin{array}{l}\text { DTPA Fe } \\
\left(\mathrm{mg} \mathrm{kg}^{-1}\right)\end{array}$} & \multirow{2}{*}{$\begin{array}{l}\text { DTPA Mn } \\
\left(\mathrm{mg} \mathrm{kg}^{-1}\right)\end{array}$} & \multirow{2}{*}{$\begin{array}{l}\text { DTPA Zn } \\
\left(\mathrm{mg} \mathrm{kg}^{-1}\right)\end{array}$} & \multirow{2}{*}{$\begin{array}{c}\text { DTPA } \\
\mathrm{Cu}\left(\mathrm{mg} \mathrm{kg}^{-1}\right)\end{array}$} & \multirow{2}{*}{$\begin{array}{c}\text { Exchangeable } \\
\text { acidity } \\
\left(\mathrm{cmolc} \mathrm{kg}^{-1}\right)\end{array}$} \\
\hline & & $\mathrm{K}$ & $\mathrm{Ca}$ & $\mathrm{Mg}$ & $\mathrm{Na}$ & & & & & & & \\
\hline \multirow{6}{*}{$\begin{array}{l}\text { Boloso } \\
\text { Sore }\end{array}$} & $\begin{array}{l}\text { Enset- } \\
\text { coffee }\end{array}$ & 0.11 & 14.60 & 6.64 & 0.39 & 23.00 & 22.90 & 165.0 & 105.0 & 10.8 & 4.83 & 0.32 \\
\hline & $\begin{array}{l}\text { Crop } \\
\text { land }\end{array}$ & 0.04 & 12.40 & 5.25 & 0.39 & 20.00 & 20.00 & 178.0 & 135.0 & 10.20 & 1.92 & 0.56 \\
\hline & $\begin{array}{l}\text { Grass } \\
\text { land }\end{array}$ & 0.05 & 13.20 & 6.96 & 0.34 & 21.00 & 21.60 & 168 & 125.0 & 10.80 & 4.98 & 0.44 \\
\hline & Means & 0.11 & 12.15 & 6.16 & 0.28 & 19.08 & 20.50 & 134.38 & 223.58 & 10.00 & 3.06 & 0.41 \\
\hline & $\begin{array}{l}\text { CV } \\
(\%)\end{array}$ & 9.28 & 4.74 & 7.14 & 10.14 & 6.05 & 2.81 & 1.75 & 2.35 & 4.80 & 8.84 & 13.82 \\
\hline & $\begin{array}{l}\text { LSD } \\
(5 \%)\end{array}$ & 0.01 & 0.48 & 0.37 & NS & 0.97 & 0.48 & 1.90 & 2.43 & 0.48 & 0.48 & NS \\
\hline
\end{tabular}

TABLE 3: Distributions of potassium forms of the soils as influenced by locations and land uses systems.

\begin{tabular}{|c|c|c|c|c|c|c|c|}
\hline \multirow{2}{*}{ Location } & \multirow{2}{*}{ Land use } & \multicolumn{6}{|c|}{ 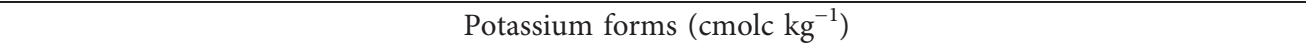 } \\
\hline & & $\mathrm{H}_{2} \mathrm{O}-\mathrm{K}$ & $\mathrm{NH}_{4} \mathrm{OAC}-\mathrm{K}$ & $\mathrm{HNO}_{3}-\mathrm{K}$ & Exchangeable-K & Nonexchangeable-K & K saturation $(\%)$ \\
\hline \multirow{3}{*}{ Sodo Zuria } & Enset-coffee & 0.33 & 0.50 & 0.40 & 0.17 & 0.23 & 0.77 \\
\hline & Crop land & 0.15 & 0.31 & 0.24 & 0.16 & 0.08 & 1.06 \\
\hline & Grass land & 0.13 & 0.27 & 0.19 & 0.14 & 0.05 & 0.82 \\
\hline \multirow{3}{*}{ Damot Gale } & Enset-coffee & 0.34 & 0.61 & 0.48 & 0.19 & 0.29 & 0.95 \\
\hline & Crop land & 0.16 & 0.23 & 0.23 & 0.07 & 0.16 & 0.46 \\
\hline & Grass land & 0.10 & 0.14 & 0.15 & 0.04 & 0.11 & 0.23 \\
\hline \multirow{3}{*}{ Damot Sore } & Enset-coffee & 0.17 & 0.35 & 0.27 & 0.18 & 0.09 & 0.78 \\
\hline & Crop land & 0.12 & 0.17 & 0.16 & 0.05 & 0.11 & 0.25 \\
\hline & Grass land & 0.13 & 0.17 & 0.14 & 0.13 & 0.01 & 0.54 \\
\hline \multirow{6}{*}{ Boloso Sore } & Enset-coffee & 0.28 & 0.39 & 0.28 & 0.11 & 0.21 & 0.47 \\
\hline & Crop land & 0.23 & 0.32 & 0.22 & 0.04 & 0.24 & 0.20 \\
\hline & Grass land & 0.13 & 0.27 & 0.18 & 0.05 & 0.17 & 0.23 \\
\hline & Means & 0.17 & 0.28 & 0.25 & 0.14 & 0.11 & 0.57 \\
\hline & CV (\%) & 9.42 & 8.37 & 7.00 & 9.29 & 8.88 & 5.85 \\
\hline & LSD (5\%) & 0.01 & 0.02 & 0.01 & 0.01 & 0.04 & 0.01 \\
\hline
\end{tabular}

minerals and release of $K$ from residues and vegetation debris, set free to soil solution which can in turn enter the interlattice spaces. This result agrees with Raheb and Heidari [4] who reported that nonexchangeable-K value ranged from 39.8 to $696.9 \mathrm{mg} \mathrm{kg}^{-1}$ for paddy and nonpaddy soils of Lebanese soils and 50 to $750 \mathrm{mg} \mathrm{kg}^{-1}$ for mineral soils [34]. The KSP soils ranged from 0.20 to $1.06 \%$ and were low in accordance with the rating of [33]. Significantly affected by land use and locations, the highest (1.06\%) was recorded under enset-coffee land as compared to grazing land, which might be that cations are held on the clay and organic matter, replaced by other cations; they are exchangeable and the total number of cations they can hold is related to the negative charge and constitutes the soil cation exchange capacity.

3.3. Thermodynamic Parameters of the Soils. The thermodynamic determinant used to evaluate the levels of potassium in soils included Woodruff energy of replacement, activity ratio, and ionic activity. The values of the ionic strengths of potassium in the soils ranging from 0.001419 to $0.007095 \mathrm{~mol} \mathrm{~L}^{-1}$ were tabulated as shown (Table 4). The highest ionic strength was $0.007095 \mathrm{~mol} \mathrm{~L}^{-1}$ under ensetcoffee land as compared to crop and grazing lands, which might be an indication for crop yields in the soils existing in active form in the soil solution. Similarly, Al-Zubaidi et al. [8] and Kenyanya et al. [43] reported on Iraqi soils. The potassium activity ratio $\left(\mathrm{AR}^{\mathrm{K}}\right)$ of the soils was tabulated as shown in Figures 3(a)-3(c) ranging from 0.04 to 0.43 (moles $\left.\mathrm{L}^{-1}\right)^{1 / 2}$, which is highly significantly $(P \leq 0.001)$ affected by the interaction effects of land uses and locations (Table 4 ) whereas the highest $\left(0.43\left(\mathrm{~mol} \mathrm{~L}^{-1}\right)^{1 / 2}\right)$ was observed under enset-coffee as compared to crop land which could be attributed to differences in the concentration of equilibrating solutions, the $\mathrm{Ca}$ and $\mathrm{Mg}$ contents, and probably the differences in the mineralogy of the soils. According to Abaslou and Abtahi [8] the soils having higher $\mathrm{K}$ fixation capacity had exchangeable Ca varying from 77 to $92 \%$ of the exchange complex. The suggested mechanism of $\mathrm{K}$ fixation is by emplacement of $\mathrm{K}$ between basal clay surfaces where it fits into the hexagonal cavities formed by tetrahedral oxygen of $2: 1$ type of clay mineral. The value of the $\mathrm{AR}^{\mathrm{K}}$ obtained in the study was lower than those reported by Al-Zubaidi [41] which fall within the range of 0.09 to $3.02\left(\mathrm{~mol} \mathrm{~L}^{-1}\right)^{0.5}$ in some Nigerian soils. However, this can lead to rapid losses 
TABLE 4: Thermodynamic parameters of the soils as influenced by locations and land use systems.

\begin{tabular}{|c|c|c|c|c|c|c|c|c|c|c|c|c|}
\hline Location & $\begin{array}{c}\text { Land } \\
\text { use }\end{array}$ & $\begin{array}{c}\mathrm{I}(\mu) \mathrm{mol} \\
\mathrm{L}^{-1}\end{array}$ & $\begin{array}{c}{\left[\mathrm{K}^{+}\right]} \\
\left(\mathrm{x} 10^{-3}\right)\end{array}$ & $\gamma \mathrm{K}$ & $\begin{array}{c}\Gamma \\
(\mathrm{Ca}+\mathrm{mg})\end{array}$ & $\begin{array}{c}{ }^{\mathrm{a}} \mathrm{K}^{+}(\mathrm{x} \\
\left.10^{-3}\right)\end{array}$ & $\begin{array}{c}\mathrm{a}(\mathrm{Ca}+\mathrm{M} \\
\left.\mathrm{g}^{2+}\right)(\mathrm{x} \\
\left.10^{-3}\right)\end{array}$ & $\mathrm{AR}^{\mathrm{K}}$ & $\begin{array}{c}(\Delta \mathrm{F}) \mathrm{cal} \\
\mathrm{mol}^{-1}\end{array}$ & $\begin{array}{c} \pm \Delta \mathrm{K} \\
\left(\mathrm{cmol} \mathrm{kg}^{-1}\right)\end{array}$ & $\begin{array}{c}\operatorname{ARe}^{\mathrm{k}}(\mathrm{mol} \\
\left.\mathrm{L}^{-1}\right)^{1 / 2}\end{array}$ & $\begin{array}{c}\mathrm{PBC}_{0}{ }^{\mathrm{k}} \\
{\left[\mathrm{cmol} \mathrm{kg}^{-1} /(\mathrm{mol}\right.} \\
\left.\left.\mathrm{L}^{-1}\right) 0.5\right]\end{array}$ \\
\hline \multirow{4}{*}{$\begin{array}{l}\text { Sodo } \\
\text { Zuria }\end{array}$} & $\begin{array}{l}\text { Enset- } \\
\text { coffee }\end{array}$ & 0.001935 & 6.76 & 0.9506 & 0.43 & 6.42 & 0.817 & 0.22 & -896.71 & 0.09 & 0.072 & 1.26 \\
\hline & $\begin{array}{l}\text { Crop } \\
\text { land }\end{array}$ & 0.006837 & 7.10 & 0.9078 & 0.21 & 6.44 & 0.294 & 0.04 & -1906.32 & 0.31 & 0.074 & 1.75 \\
\hline & $\begin{array}{c}\text { Grass } \\
\text { land }\end{array}$ & 0.005418 & 8.32 & 0.9183 & 0.25 & 7.64 & 0.400 & 0.38 & -571.10 & 0.12 & 0.071 & 1.48 \\
\hline & $\begin{array}{l}\text { Enset- } \\
\text { coffee }\end{array}$ & 0.001419 & 7.66 & 0.9569 & 0.49 & 7.32 & 0.931 & 0.24 & -842.20 & 0.05 & 0.062 & 0.80 \\
\hline \multirow[t]{3}{*}{$\begin{array}{l}\text { Damot } \\
\text { Gale }\end{array}$} & $\begin{array}{l}\text { Crop } \\
\text { land }\end{array}$ & 0.004128 & 7.57 & 0.9274 & 0.29 & 7.02 & 0.435 & 0.33 & -323.83 & 0.11 & 0.069 & 1.59 \\
\hline & $\begin{array}{c}\text { Grass } \\
\text { land }\end{array}$ & 0.005547 & 8.14 & 0.9164 & 0.24 & 7.45 & 0.336 & 0.41 & -528.03 & 0.10 & 0.074 & 1.35 \\
\hline & $\begin{array}{l}\text { Enset- } \\
\text { coffee }\end{array}$ & 0.002709 & 7.85 & 0.9410 & 0.37 & 7.38 & 0.592 & 0.30 & -713.03 & 0.10 & 0.066 & 1.51 \\
\hline \multirow[t]{3}{*}{$\begin{array}{l}\text { Damot } \\
\text { Sore }\end{array}$} & $\begin{array}{l}\text { Crop } \\
\text { land }\end{array}$ & 0.004257 & 7.22 & 0.9264 & 0.29 & 6.68 & 0.555 & 0.29 & -733.10 & 0.11 & 0.066 & 1.66 \\
\hline & $\begin{array}{c}\text { Grass } \\
\text { land }\end{array}$ & 0.002967 & 7.53 & 0.9382 & 0.36 & 7.06 & 0.612 & 0.29 & -733.10 & 0.11 & 0.071 & 1.54 \\
\hline & $\begin{array}{l}\text { Enset- } \\
\text { coffee }\end{array}$ & 0.007095 & 7.65 & 0.9061 & 0.20 & 6.93 & 0.360 & 0.43 & -2076.6 & 0.11 & 0.064 & 1.71 \\
\hline \multirow[t]{6}{*}{$\begin{array}{l}\text { Boloso } \\
\text { Sore }\end{array}$} & $\begin{array}{l}\text { Crop } \\
\text { land }\end{array}$ & 0.005547 & 8.13 & 0.9164 & 0.24 & 7.45 & 0.312 & 0.38 & -573.03 & 0.09 & 0.049 & 2.00 \\
\hline & $\begin{array}{c}\text { Grass } \\
\text { land }\end{array}$ & 0.006708 & 7.00 & 0.8978 & 0.21 & 6.28 & 0.336 & 0.34 & -693.61 & 0.12 & 0.067 & 1.79 \\
\hline & Means & 0.004547 & 6.19 & 0.92 & 0.29 & 7.00 & 0.49 & 0.30 & -884.1 & 0.11 & 0.07 & 1.53 \\
\hline & $\begin{array}{l}\text { CV } \\
(\%)\end{array}$ & 6.60 & 7.57 & 1.12 & 9.54 & 6.25 & 6.22 & 7.65 & -30.68 & 9.20 & 6.57 & 7.59 \\
\hline & $\begin{array}{c}P \\
\text { Value }\end{array}$ & $<0.001$ & 0.0610 & $<0.001$ & $<0.001$ & 0.210 & $<0.001$ & $<0.001$ & 0.002 & $<0.001$ & $<0.001$ & $<0.001$ \\
\hline & $\begin{array}{l}\text { LSD } \\
(5 \%)\end{array}$ & 0.001 & NS & 0.008 & 0.04 & NS & 0.10 & 0.06 & 272.92 & 0.03 & 0.001 & 0.09 \\
\hline
\end{tabular}

$\mathrm{I}=$ ionic strength, $\mathrm{ARe}^{\mathrm{k}}\left(\mathrm{mol} \mathrm{L}^{-1}\right)^{1 / 2}=$ equilibrium activity ratio; $\mathrm{PBC}^{\mathrm{K}}$ : potential buffering capacity $\left[\mathrm{cmol} \mathrm{kg}^{-1} /\left(\mathrm{mol} \mathrm{L}^{-1}\right)^{0.5}\right],\left[\mathrm{K}^{+}\right]=\mathrm{K}$ concentration $(\mathrm{mol}$ $\left.\mathrm{L}^{-1}\right), \gamma \mathrm{K}=$ activity coefficient of $\mathrm{K},{ }^{\mathrm{a}} \mathrm{K}=$ activity of $\mathrm{K}\left(\mathrm{mol} \mathrm{L}^{-1}\right), \gamma \mathrm{Ca}+\mathrm{Mg}=$ activity coefficient of $\mathrm{Ca}+\mathrm{Mg},{ }^{\mathrm{a}}\left(\mathrm{Ca}^{2+}+\mathrm{Mg}^{2+}\right)=$ activity of Ca $+\mathrm{Mg}, \mathrm{ARK}=$ activity ratio of $\mathrm{K}, \pm \Delta \mathrm{K}=$ gain/loss of $\mathrm{K}\left(\mathrm{cmol} \mathrm{kg}{ }^{-1}\right)$, NS = nonsignificant.

of $\mathrm{K}$ through leaching. The free energy of replacement $(\Delta \mathrm{F})$ of the soils varied from -2076.6 to $-323.83 \mathrm{cal} \mathrm{mol}^{-1}$, where the upper value $\left(-2076.6 \mathrm{cal} \mathrm{mol}^{-1}\right)$ indicates $\mathrm{K}$ sufficiency, and the lower value $\left(-323.83 \mathrm{cal} \mathrm{mol}^{-1}\right)$ indicates $\mathrm{K}$ deficiency in accordance with the rating of Woodruff [29]; this might be attributed to intensive cropping, fertilizer application, moisture content, and organic matters accumulation variation under different land use types. This result is in agreement with that of Kenyanya et al. [43] ranging from -3632 to $-3523 \mathrm{cal} \mathrm{mol}^{-1}$ in some agricultural soils of Nyamira, Kenya. Equilibrium activity ratio of the soils ranged from 0.049 to $0.074\left(\mathrm{~mol} \mathrm{~L}^{-1}\right)^{1 / 2}$ and was lower according to Yawson et al. [44]; the suggested values are 0.02 to $0.12\left(\mathrm{~mol} \mathrm{~L}^{-1}\right)^{1 / 2}$. It was highly significantly $(P \leq 0.001)$ affected by the interaction effects of land uses and locations (Table 4$)$ whereas the highest $\left(0.074\left(\mathrm{~mol} \mathrm{~L}^{-1}\right)^{1 / 2}\right)$ was observed under grazing land as compared to crop land which could be attributed to greater $\mathrm{K}$ release into soil solution because these soils contain comparatively high amount of exchangeable calcium and magnesium values which increase the $\mathrm{ARe}^{\mathrm{K}}$ value. Similarly, Samadi [45] reported that. The potential buffering capacity in the soils ranged from 0.80 to $2.0 \mathrm{cmol} \mathrm{kg}^{-1} /\left(\mathrm{mol} \mathrm{L}^{-1}\right)^{1 / 2}$ as shown in Table 4 , which is highly significantly $(P \leq 0.001)$ affected by the interaction effects of land uses and locations whereas the highest (2.0 $\left.\mathrm{cmol} \mathrm{kg}^{-1} /\left(\mathrm{mol} \mathrm{L}^{-1}\right)^{1 / 2}\right)$ was observed under crop land as compared to enset-coffee which could be attributed to lowest amount of clay content and highest amount of clay content and CEC, respectively. The values of $\mathrm{PBC}^{\mathrm{K}}$ observed in both land use indicated low potassium supplying capacity of these soils and frequent fertilization for optimum crop yield. Consequently, low $\mathrm{PBC}^{\mathrm{K}}$ indicates that $\mathrm{AR}^{\mathrm{K}}, \mathrm{K}$-intensity in the soil solution, and hence availability of $\mathrm{K}$ to plants will drop rapidly when the soils are cultivated. This result was in agreement with that of Hosseinpournda Kalbasi [46] who observed that soils with the greatest $\mathrm{PBC}^{\mathrm{K}}$ values were characterized by the lowest percentage of $\mathrm{K}$ saturation, indicative of greater potential to replenish $\mathrm{K}$ concentration in soil solution. The change in exchangeable potassium $( \pm \Delta \mathrm{K})$ ranged from 0.05 to $0.31 \mathrm{cmolc} \mathrm{kg}^{-1}$ (Table 4 and Figures 3(a)-3(c)), highly significantly $(P \leq 0.001)$ affected by the interaction effects of land uses and locations, whereas 


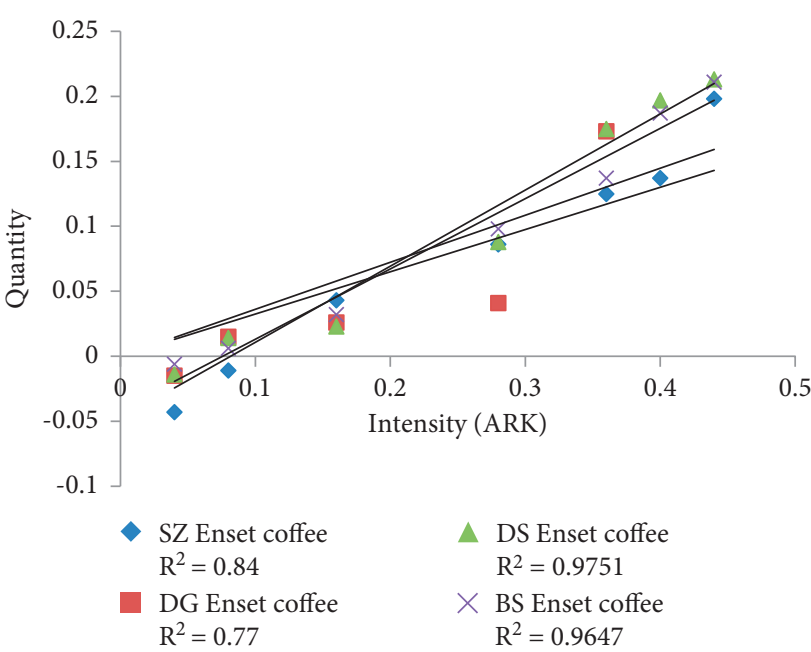

(a)

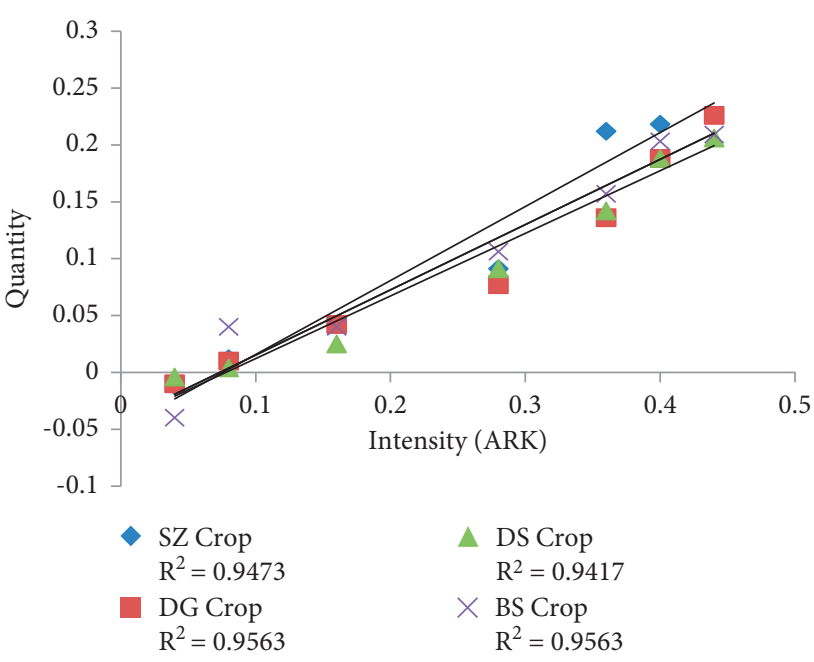

(b)

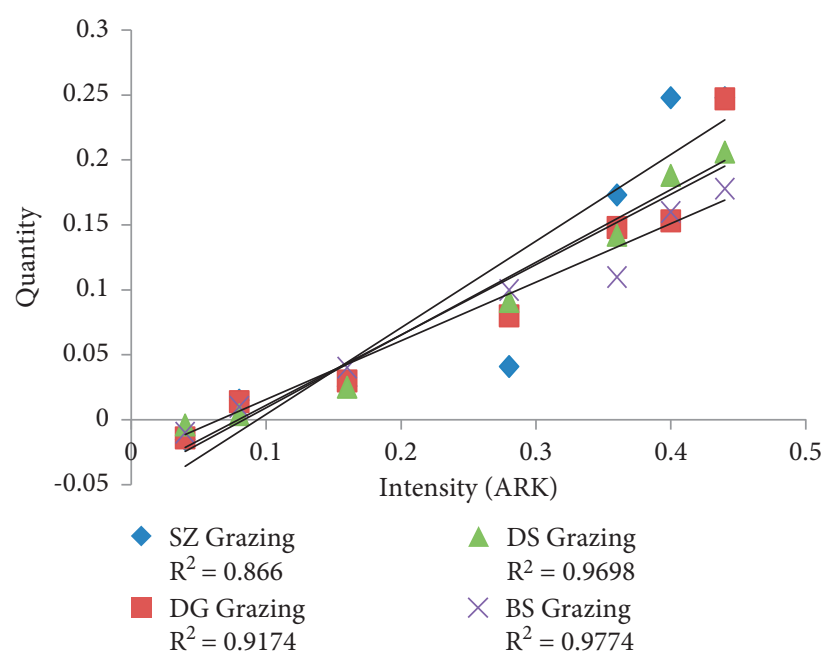

(c)

Figure 3: (a). The quantity-intensity isotherms of enset-coffee complex soils. (b) The quantity-intensity isotherms of crop land soils. (c) The quantity-intensity isotherms of grazing land soils.

the highest $\left(0.31 \mathrm{cmol} \mathrm{kg}^{-1}\right)$ was observed under crop land as compared to enset-coffee land which could be attributed to differences in equilibration analysis that these values also increased at increasing concentrations of the equilibration solutions. However, the values are lower than those reported by Yawson [44] which ranged from 1.30 to 1.33 at Ghana soils.

3.4. Correlation between Soil Properties and Soil Potassium. The correlation analysis indicated that soil $\mathrm{pH}$ is significantly positively correlated with exchangeable $\mathrm{Mg}^{2+}$ and $\mathrm{K}^{+}$and CEC $\left(r=0.98^{* * *}, r=0.98^{* * *} ; r=0.96^{* *}\right)$, respectively, but negatively correlated with exchangeable $\mathrm{Ca}(r=-0.22)$. The
CEC positively and significantly correlated with clay $\left(r=0.97^{* * *}\right)$; OC $\left(r=0.96^{* * *}\right)$ (Table 4$)$. There are positive and highly significant correlations of $\mathrm{H}_{2} \mathrm{O}-\mathrm{K}$ with the clay $\left(r=0.83^{* *}\right)$ fraction. However $\mathrm{H}_{2} \mathrm{O}-\mathrm{K}$ has negative and significant correlation with soil $\mathrm{pH}\left(r=-0.17^{*}\right)$ and is positively correlated with exchangeable-K $(r=0.13)$ and nonexchangeable-K $(r=0.40)$. Also, the correlation coefficients between $\mathrm{NH}_{4} \mathrm{OAC}-\mathrm{K}$ and exchangeable-K, clay content, and CEC of the studied soils were positively significant $\left(r=0.96^{* * *} ; r=0.98^{* * *} ; r=0.98^{* * *}\right)$, respectively; exchangeable-K was correlated positively with clay content $\left(r=0.95^{* * *}\right)$ and OC was positively and significantly correlated with $\mathrm{NH}_{4} \mathrm{OAC}-\mathrm{K}\left(r=0.95^{* * *}\right)$, exchangeable-K $\left(r=0.95^{* * *}\right)$, and $\operatorname{AR}^{\mathrm{K}}\left(r=0.95^{* * *}\right)$ (Table 5) which is very 
TABLE 5: Linear coefficients of correlation between potassium forms and quantity-intensity parameters.

\begin{tabular}{|c|c|c|c|c|c|c|c|c|}
\hline Properties & $\mathrm{H}_{2} \mathrm{O}-\mathrm{K}$ & $\mathrm{NH}_{4} \mathrm{OAC}-\mathrm{K}$ & $\mathrm{HNO}_{3}-\mathrm{K}$ & Exchangeable- $\mathrm{K}$ & Nonexchangeable- $\mathrm{K}$ & $\mathrm{AR}^{\mathrm{K}}$ & $\Delta \mathrm{K}$ & $\mathrm{PB}_{\mathrm{C}}{ }^{\mathrm{K}}$ \\
\hline Sand & -0.05 & -0.98 & -0.02 & -0.98 & -0.23 & -0.95 & 0.24 & -0.27 \\
\hline Silt & 0.23 & -0.43 & -0.22 & -0.43 & -0.10 & -0.4 & -0.12 & -0.11 \\
\hline Clay & 0.05 & $0.98^{* * *}$ & 0.02 & $0.98^{* * *}$ & -0.23 & $0.95^{* * *}$ & -0.24 & -0.27 \\
\hline $\mathrm{pHH}_{2} \mathrm{O}$ & -0.17 & -0.13 & -0.15 & 0.13 & 0.40 & 0.13 & 0.34 & -0.14 \\
\hline $\mathrm{OC}$ & 0.50 & $0.95^{* * *}$ & 0.02 & $0.95^{* * *}$ & -0.23 & $0.95^{* * *}$ & 0.24 & -0.27 \\
\hline Ex.K & 0.11 & $0.96^{* * *}$ & 0.004 & $0.96^{* * *}$ & -0.24 & $0.96^{* * *}$ & 0.38 & -0.27 \\
\hline Ex.Ca & $0.56^{* *}$ & -0.22 & -0.03 & -0.22 & -0.04 & -0.22 & -0.08 & -0.13 \\
\hline Ex.Mg & 0.11 & 0.96 & 0.004 & 0.96 & -0.24 & 0.96 & 0.38 & -0.27 \\
\hline Ex.Na & 0.01 & -0.33 & 0.12 & -0.33 & -0.11 & -0.33 & 0.01 & 0.17 \\
\hline CEC & 0.10 & $0.98^{* * *}$ & 0.01 & $0.98^{* * *}$ & -0.27 & $0.98^{* * *}$ & 0.38 & -0.27 \\
\hline
\end{tabular}

much expected because of the fact that higher content of OC in the soil leads to higher CEC resulting in higher adsorption of the cations including $\mathrm{K}$.

\section{Conclusions}

The present study revealed that land use systems are useful in explaining potassium buffering behavior in soils with low levels of exchangeable- $K$ through partitioning quantity factor in exchangeable- and nonexchangeable- $K$ form. Moreover, the use of potassium forms and dynamics as a soil test that takes into account nonexchangeable- $K$ and exchangeable-K was documented by quantity-intensity experiments. Finally, $\mathrm{K}^{+}$intensity and activity lead to a lower $\mathrm{PBC}^{\mathrm{K}}$ which is a better indicator of the ability of soil to maintain K-intensity. In all, considering the values of $\mathrm{K}$-potential and the free energy of exchange, land use systems have a high capacity to supply $\mathrm{K}$ but the crop lands have a higher capacity to replenish the solution $\mathrm{K}$ due to the fact that $\mathrm{Q} / \mathrm{I}$ parameters of $\mathrm{K}$-depleted soils can be used to predict corresponding Q/I parameters in their initial state of chemical equilibrium, which could be useful in potassium management and fertilization recommendations.

\section{Data Availability}

The data used to support the findings of this study are available from all authors upon request.

\section{Conflicts of Interest}

The authors declare that they have no conflicts of interest.

\section{Authors' Contributions}

Mesfin Kassa, Fassil Kebede, and Wassie Haile contributed equally to this study.

\section{Acknowledgments}

The authors acknowledge the staff members of Department of Plant Science, Wolaita Sodo University, and Hawassa Research Center of Soil Laboratory, for providing them with the necessary support to conduct this study. This work was supported by Ethiopian Ministry of Education and Wolaita Sodo University.

\section{References}

[1] R. George and S. Michael, Potassium for Crop Production, pp. 876-8636, University of Minnesota Extension, St Paul, MN, USA, 2002.

[2] D. L. Sparks, "Bioavailability of soil potassium, D-38-D-52," in Handbook of Soil Science, M. E. Sumner, Ed., CRC Press, Boca Raton, FL, USA, 2000.

[3] W. Darryl, D. L. J. Jon, and L. Carrie, Nutrients Recommendation for Field Crops in Michigan. Extension Bulletin E2904, Department of Crop and Soil Sciences Michigan State University, East Lansing, MI, USA, 2004.

[4] M. Rahmatullah and K. Mengel, "Potassium release from mineral structures by $\mathrm{H}^{+}$ion resin," Geoderma, vol. 96, pp. 29 1-305, 2000.

[5] A. G. Ajiboye, O. Jamiu, Azeez, J. Akinwande, and Omotunde, "Potassium forms and quantity intensity relationships in some wetland soils of Abeokuta, Southwestern Nigeria," Archives of Agronomy and Soil Science, vol. 61, no. 10, pp. 139-140, 2015.

[6] B. Otobong, "Forms and status of potassium in some soils supporting oil palm (Elaeisguineensis,Jacq) plantations in CrossRiver state, Nigeria," Communications in Soil Science and Plant Analysis, vol. 43, pp. 1949-1962, 2012.

[7] J. J. Wang, D. L. Harrell, and P. F. Bell, "Potassium buffering characteristics of three soils low in exchangeable potassium," Soil Science Society of America Journal, vol. 68, no. 2, pp. 654-661, 2004.

[8] H. Abaslou and A. Abtahi, "Potassium quantity-intensity parameters and its correlation with selected soil properties in some soils of Iran," Journal of Applied Sciences, vol. 8, no. 10, 2008.

[9] A. G. Ajiboye and A. J. Ogunwale, "Forms and distribution of potassium in particle size fractions on talc overburden soils in Nigeria," Archives of Agronomy and Soil Science, vol. 59, no. 2, pp. 247-258, 2013.

[10] M. N. Ghiri, A. Abtahi, H. Owliaie, S. S. Hashemi, and H. Koohkan, "Factors affecting potassium pools distribution in calcareous soils of southern Iran," Arid Land Research and Management, vol. 25, no. 4, pp. 313-327, 2011.

[11] A. Hannan, Evaluation of sorption isotherm based soil solution potassium concentration levels for maximizing crop yields, $\mathrm{PhD}$ Thesis in Soil Science, Institute of soil and environmental sciences, University of Agriculture, Faisalabad, 2008.

[12] W. Haile and T. Mamo, The Effect of Potassium on the Yields of Potato and Wheat Grown on the Acidic Soils of Chencha and Hagere Selam in Southern Ethiopia, International Potash Institute, 2013. 
[13] M. Kassa, W. Haile, and F. Kebede, "Evaluation of adsorption isotherm models for potassium adsorption under different soil types in Wolaita of southern Ethiopia," Communications in Soil Science and Plant Analysis, vol. 50, no. 4, pp. 388-401, 2019.

[14] NMA (National Meteorological Agency), "National meteorological agency, Hawassa meteorological service center, Ethiopia," 2016.

[15] B. Mesfin, T. Abi, G. Heluf, and M. Asmare, "Evaluation of universal extractants for determination of some macronutrients from soil communications in soil science and plant analysis," 2015.

[16] B. Tesfaye, Understanding Farmers, Wageningen University and Research Center, Wageningen, 2003.

[17] S. Sertsu and B. Taye, Procedures for Soil and Plant Analysis. Technical Paper 74, National Soil Research Center, Ethiopian Agricultural Research Organization, Addis Ababa, Ethiopia, 2000.

[18] P. R. Day, Hydrometer Method of Particle Size Analysis: Methods of Soil Analysis. Agronomy. Part II, No. 9, C. A. Black, Ed., pp. 562-563, American Society of Agronomy, Madison, Wisconsin, USA, 1965.

[19] A. L. Page, Methods of Soil Analysis. Part 2, Chemical and Microbiological Properties, Madison, Wisconsin, USA, 1982.

[20] A. J. Walkley and I. A. Black, "Estimation of soil organic carbon by the chromic acid titration method," Soil Science, vol. 37, pp. 29-38, 1954.

[21] M. L. Jackson, Soil Chemical Analysis, p. 284, Prentice Hall Grice, Englewood CF, USA, 1973.

[22] R. H. Bray and L. T. , Kurtz, "Determination of total, organic, and available forms of phosphorus in soils," Soil Science, vol. 59, no. 1, pp. 39-46, 1945.

[23] M. F. Morgan, "Chemical diagnosis by the universal soil testing system," The Connecticut Agricultural Experiment Station, vol. 450, 1941.

[24] H. D. Chapman, "Cation exchange capacity by ammonium saturation. 891-901," in Method of Soil Analysis, C. A. Black, L. E. Ensminger, and F. E. Clark, Eds., American Society of Agronomy, Madison, Wisconsin, USA, 1965.

[25] K. H. Tan, Soil Sampling, Preparation and Analysis, p. 68, Marcel Dekker, New York, NY, USA, 1996.

[26] P. F. Pratt, "Potassium," in Methods of Soil Analysis, Part 2.Agronomy 9: 1023 - 1031. Amer. Soc. Of Agron., C. A. Black, Ed., Meddison, Wiz, 1965.

[27] A. Samadi, B. Dovlati, and M. Barin, "Effect of continuous cropping on potassium forms and potassium adsorption characteristics in calcareous soils of Iran," Soil Research, vol. 46, no. 3, pp. 265-272, 2008.

[28] G. P. Griffin and J. J. Jurinak, "Estimation of Activity Coefficient from Electrical Conductivity of natural aquatic systems and soil extracts," Soil Science Journal, vol. 116, 1993.

[29] C. M. Woodruff, "The energies of replacement of calcium by potassium in soils," Soil Science Society of America Journal, vol. 19, no. 2, pp. 167-171, 1955.

[30] P. Hazelton and B. Murphy, Interpreting Soil Test Results. What Do All the Numbers Mean?, CSIRO publishing, Australia, 2007.

[31] Y. Ishibashi, H. Matsuo, Y. Baba, Y. Nagafuchi, T. Imato, and T. Hirata, "Association of manganese effluent with the application of fertilizer and manure on tea field," Water Research, vol. 38, no. 12, pp. 2821-2826, 2004.

[32] G. Yihenew, "Selected chemical and physical characteristics of soils of Adet Research Center and its testing sites in north western Ethiopia," Ethiopia. J. Nat. Res.vol. 4, no. 2, pp. 199-215, 2002.

[33] J. R. Landon, Ed., Booker Tropical Soil Manual: A Handbook for Soil Survey and Agricultural Land Evaluation in the Tropics and Subtropics, p. 474, Longman Scientific and Technical, Essex, NY, USA, 1991.

[34] K. Alemayehu and B. Sheleme, "Effects of different land use systems on selected soil properties in South Ethiopia," Journal of Soil Science and Environmental Management, vol. 4, no. 5, pp. 100-170, 2013.

[35] International Potash Institute (IPI), Potassium Dynamics and its Availability, pp. 1-5, International Fertilizer Correspondent, 2001.

[36] A. Al-Zubaidi, S. Yanni, and I. Bashour, "Potassium status in some Lebanese soils," Lebanese Science Journal, vol. 9, no. 1, pp. 81-97, 2008.

[37] A. Raheb and A. Heidari, "Clay mineralogy and its relationship with potassium forms in some paddy and non-paddy soils of northern Iran," Australian Journal of Agricultural Engineering, vol. 2, no. 6, pp. 169-175, 2011.

[38] T. Darwish, T. Nasri, M. El Moujabber, and T. Atallah, "Impact of soil nature and mineral composition on the management and availability of potassium in Lebanese soils," in Proceedings of the Regional Workshop: "Potassium and Water Management in West Asia and North Africa.", A. E. Johnston, Ed., pp. 152-160, International Potash Institute, Zug, Switzerland, 2003.

[39] T. Ayele, "Potassium availability under banana- based land use systems in abay chamo lake basin, south-west Ethiopia," International Journal of Scientific Research and Reviews, vol. 2, no. 2, p. 94, 2013.

[40] K. Ngwe, K. Irb, and A. Suddhiprakarn, "Potassium status and physicochemical and mineralogical properties of lowland vertisols in a rice-based cropping system under tropical savanna climate. Kasetsart," Journal natural science, vol. 46, pp. 522-537, 2012.

[41] A. Al-Zubaidi, "Potassium status in Iraqi soils," in Proceedings of the Regional workshop: "Potassium and Water Management in West Asia and North Africa, A. E. Johnston, Ed., pp. 129-142, International Potash Institute, Zug, Switzerland, 2003.

[42] C. Srinivasarao, K. P. R. Vittal, K. N. Tiwari, P. N. Gajbhiye, and S. Kundu, "Categorisation of soils based on potassium reserves and production systems: implications in $\mathrm{K}$ management," Soil Research, vol. 45, no. 6, pp. 438-447, 2007.

[43] O. Kenyanya, J. Muthengia, and H. Mbuvi, "Determination of potassium levels in intensive subsistence agricultural soils in Nyamira county, Kenya," Chemistry Department Kenyatta University, vol. 3, no. 7, pp. 294-302, 2013.

[44] D. O. Yawson, P. K. Kwakye, F. A. Armah, and K. A. Frimpong, "The dynamics of potassium in representative soil series of Ghana," Journal of Agricultural and Biological Science, vol. 6, no. 1, pp. 48-55, 2011.

[45] A. Samadi, "Potassium exchange isotherms as a plant availability index in selected calcareous soils of Western Azarbaijan Province, Iran," Turkey Journal of Agriculture, vol. 30, pp. 213-222, 2006.

[46] A. Hosseinpour and M. Kalbasi, "Kinetics of non-exchangeable potassium release from soils and soil separates in some central region of Iran," in Proceedings of the 17th WCSS, p. 231, Thailand, August 2002. 